\title{
ФОРМУВАННЯ У СТУДЕНТІВ-ФІЛОЛОГІВ ІНШОМОВНИХ МОВЛЕННСВИХ НАВИЧОК ПІД ЧАС ВИВЧЕННЯ ТВОРІВ МАЛОЇ НІМЕЦЬКОМОВНОЇ ПРОЗИ
}

\author{
Лебсдсва О. А. \\ старший викладач кафедри методики викладання германських мов \\ Мелітопольський державний педагогічний університет імені Богдана Хмельнииького \\ вул. Гетьманська, 20, Мелітополь, Запорізька область, Украӥна \\ orcid.org/0000-0003-0985-5462 \\ slz.melitopol@gmail.com
}

\begin{abstract}
Ключові слова: оригінальні літературні твори іноземною мовою, мала німецькомовна проза, інтегруючий характер навчання, філологічне розуміння оригінальної художньої літератури, соиіальні компетентності.
\end{abstract}

\begin{abstract}
У статті розглянуто проблему підготовки сучасного філолога-германіста 3 точкизору вибору методів роботиз оригінальними літературнимитекстами жанру малої прози, які б ефективно сприяли формуванню іншомовних мовленнєвих навичок. 3'ясоване місце оригінальних художніх творів в загальній конфігурації навчання іноземній мові та культурі. Виявлено значення впливу першого позитивного досвіду зустрічі з німецькомовною літературою у формі малої прози на подальше ставлення студентів до складних, обширних та високодиференційованих з огляду на їх зміст та форму оригінальних літературних творів. Висвітлено, що для досягнення позитивного впливу на формувння у студентів-філологів іншомовних мовленнєвих навичок через вивчення оригінальних літературних творів слід забезпечити безпосередній взаємозв'язок між прагматичною складовою частиною, з одного боку, та естетичною і етичною складовими частинами оригінальної художньої літератури іноземною мовою, 3 іншого. Встановлено, що таке узгодження виражається в необхідному корегуванні навчального процесу, тобто відбувається за умов включення до навчальної програми творів малої німецькомовної прози, попередньо дидактизованих викладачем. На цій підставі обгрунтовано, що робота 3 оригінальними літературними текстами під час вивчення іноземної мови повинна мати інтегруючий характер, який поєднує три предметні галузі: літературу, мову, країнознавство. 3'ясована роль викладача у підвищенні мотивації здобувачів освіти в аспекті оволодіння мовою через досягнення цілей, що поєднують естетичний характер літературних текстів з іншокультурним аспектом. На окремому практичному прикладі продемонстровано, які форми можуть мати завдання до текстів на рівні осмислення конкретних навчально-методичних кроків їх реалізації, аби досягти мети всебічного розвитку філологічного розуміння оригінальної художньої літератури іноземною мовою та ефективного формування іншомовних мовленнєвих навичок. Зазначено, що, запроваджуючи розвиток іншомовних мовленнєвих компетенцій студентів через вивчення оригінальних літературних творів, викладач іноземних мов повинен одночасно сприяти розвитку соціальних компетентностей, бажанню спілкуватися та готовності до розмови, розвивати вміння робити судження, вчити критичній оцінці, формувати особистість, давати імпульс для роздумів та соціально орієнтованого спілкування.
\end{abstract}




\title{
DEVELOPMENT OF FOREIGN LANGUAGE SPEAKING SKILLS OF PHILOLOGY STUDENTS BY LEARNING SHORT PROSE IN GERMAN LANGUAGE
}

\author{
Lebyedyeva O. A. \\ Senior Lecturer at the Department of Methods for Teaching Germanic Languages \\ Bogdan Khmelnytsky Melitopol State Pedagogical University \\ Hetmanska str., 20, Melitopol, Zaporizhzhia region, Ukraine \\ orcid.org/0000-0003-0985-5462 \\ slz.melitopol@gmail.com
}

\begin{abstract}
Key words: foreign original literary works in a foreign language, German-language short prose, integrative nature of learning, philological understanding of original fiction, social skills.
\end{abstract}

\begin{abstract}
The article analyses the preparation of modern German philologists in relation to the selection of learning methods connected with original literary short prose texts that would effectively contribute to the formation of the foreign language skills. There is determined the importance of working on original literary texts in the general configuration of teaching a foreign language and culture. There is considered the significance of the first positive experience in learning German-language literature in the form of a short prose for the further attitude of the students to complex, extensive in terms of content and form original literary works. It is pointed out that in order to achieve a positive impact on the development of foreign language skills of philology students through the study of original literary works, there must be a direct connection between the pragmatic component, on the one hand, and aesthetic and ethical components of original literary short prose, on the other hand. It is noted that such a coordination needs a necessary adjustment of the educational process, that occurs under the conditions of adding of previously didactized by the teacher short German-language prose to the curriculum. On this basis, it is substantiated that the work with original literary texts in the study of a foreign language should have an integrative nature, which combines three subject fields: literature, language, cultural studies. The article is pointing out the role of the teacher in developing the motivation of students through the reaching of learning goals that combine understanding the aesthetic nature of literary texts with a foreign culture aspect. There is a practical example that shows possible forms of tasks to texts at the level of comprehension of concrete educational and methodical steps of their realization to reach the purpose of comprehensive development of philological understanding of original fiction in a foreign language and therefore effective formation of the foreign language skills. It is noted that by introducing the development of foreign language competences of students through the study of original literary works, the teacher of foreign languages should also promote the development of social competencies, a wish to communication, critical thinking, the development of personality to give students the impulse for a socially oriented communication.
\end{abstract}

Пріоритети та освітні цілі в підготовці сучасного філолога-германіста є значною мірою визначальними для вибору методів роботи з літературними текстами. Як підтверджує практика, перша зустріч 3 німецькомовною літературою має значний вплив на подальше ставлення студентів до складних, обширних та високодиференційованих 3 огляду на їх зміст та форму оригінальних літературних творів. Перший позитивний досвід спонукає студента до бажання та необхідності отримати якомога більше від літературного твору, проникнути під поверхню писемної мови та зрозуміти літературні тексти як відкриті структури. Крім того, він формує особисті емоційні стосунки 3 літературою. Простий переказ тексту, або заучування мовних структур, чи виключно автоматизовані вправи або ж письмові тести, які перевіряють знання лексики твору, якщо їх розглядати в перспективі, в значній мірі гальмують розвиток потенційного філологічного розуміння естетичної 
складової оригінальної художньої літератури іноземною мовою.

Чому взагалі слід читати оригінальні художні тексти іноземною мовою? Протягом кількох десятиліть викладання іноземної мови $є$ діяльнісно орієнтованим та визначається комунікативним підходом, тобто студенти набувають компетентностей, які потім допомагають їм спілкуватися та успішно діяти в реальних іншомовних ситуаціях [8, с. $1530 ; 6$. с. 94]. У такій концепції літературні тексти в основному використовуються для тренування та контролю розуміння прочитаного або як джерело іншокультурної країнознавчої інформації. Літературні тексти майже відсутні у перевіжній більшості підручників, тому що вони нібито неактуальні і не пропонують жодних автентичних ситуацій. «Відповідно до цієї цільової орієнтації підручники зосереджені на формуванні навичок усного мовлення, за яких кращими типами тексту вважаються діалоги і повсякденні практичні тексти. Літературні тексти в значній мірі «заборонені», тому що вони вважаються занадто складними, занадто довгими і дуже далекими від вимог повсякденного спілкування, або ж вони використовуються для вивчення мови без урахування їх літературно-естетичного характеру » $[8$, с. 1530]. Все це вже у 80-х рр. ХХ ст. призвело до критики такої концепції. Аргументами було те, що вивчення іноземної мови та контакти 3 цільовою мовною культурою здійснюються переважно за допомогою текстів, і що літературні тексти, на відміну від підручників, надають більше поштовху для реального спілкування. Крім того, «літературні тексти сприяють соціальному, емоційному та когнітивному розвитку студентів, заохочуючи ідентифікацію, обробляючи та диференціюючи змістовні поняття ( таких як персонажі, ситуації, подіiі) та коригуючи те, що студент приносить із собою з точки зору світогляду та ставлення» [8, с. 1531]. У Р. Крехеля ми знаходимо таке міркування: літературні тексти «відкривають широке поле емоційних компонентів мови для тих, хто вивчає іноземну мову, і намагаються прорватися через суто раціональне засвоєння іншомовного словника і граматики» [7, с. 82]. Й. Ріме підкреслює: «Унікальність літератури в тому, що за допомогою специфічних засобів мистецтва вона дає уявлення про культуру відповідної країни та реальність, зображену засобами мистецтва» [13, с. 13]. М. Льошман / Г. Шрьодер зауважили, що література «розширює область досвіду, підтримує формування ідеологічних установок, збагачує світ емоцій, естетичних відчуттів, стимулює уяву, загострює судження, підвищує здатність переживати». Іншими словами, це «впливає на інтелектуально-практичну поведінку людини» [9, с. 18]. Місце літератури у викладанні іно- земних мов було переосмислене. 3 одного боку, художні тексти підпорядковувались цілям оволодіння мовою; з іншого боку, існували також цілі, що поєднують естетичний характер літературних текстів 3 культурним аспектом. Останнє переважало $з$ 1990-х років, коли література набула все більшого значення як джерело інформації щодо країнознавчих і культурних реалій. Було підкреслено, що літературні тексти $є$ «носіями культурного змісту» i «можуть з'ясувати відмінності між власною та чужою культурами» [8, с. 1535].

Робота 3 оригінальними літературними текстами під час вивчення іноземної мови повинна мати інтегруючий характер, тобто слід зробити спробу поєднати три предметні галузі: література, мова, країнознавство. Саме тому важливо, аби викладач визнав роль та місце оригінальних художніх творів в загальній конфігурації навчання іноземній мові та культурі і свідомо включав до навчального курсу канонічні художні тексти, особливо, якщо такі відсутні у підручнику. Мала проза якнайкраще відповідає критеріям інтегративного навчання, поєднуючи в собі прагматичне, етичне та естетичне. Проблеми, що їх піднімають невеликі за розміром тексти, притаманні культурі країн, мова яких вивчається, носять загальний характер і тому знаходять особистий відгук у студентів і бажання висловити власну думку і власне сприйняття того чи іншого аспекту твору. Розвиток іншомовних мовленнєвих навичок відбувається завдяки цьому дійсно природньо і відповідає інтенції студентів висловитися на тему, що дійсно чіпляє. Роль викладача вбачається при цьому як така, що відкриє студентові глибокі етичні, естетичні та лінгвістичні шари твору та вдало дидактизує його, аби завдання, які опрацьовиватимуть студенти сприяли успішному формуванню у студентів-філологів іншомовних мовленнєвих навичок.

Тому метою даної статті $\epsilon$, виходячи 3 важливої ролі оригінальних німецькомовних художніх текстів для професійної підготовки студентів-філологів, запропонувати можливий комплекс завдань для роботи 3 художніми текстами жанру малої прози на практичних заняттях 3 німецької мови, які носять інтегруючий характер і завдяки своїй варіативності сприятимуть успішному формуванню у студентів-філологів іншомовних мовленнєвих навичок.

Щодо відбору літературних текстів німецькомовних письменників в контексті навчання німецької мови, то потрібно зауважити, що для студентів-германістів існує канон для читання, який включає близько 30 авторів і пропонує досить репрезентативну добірку стосовно жанрової специфіки, тематики та художнього стилю німецькомовних літературних творів після 1945 року. 
Серед авторів - Г. Бьолль, 3. Ленц, Г. Грас, М. Вальсер, I. Айхінгер, М. Фріш, Т. Бернгард, Г. Вальрафф, М. фон дер Грюн, та інші. Основною передумовою $\epsilon$ розгляд таких оригінальних текстів як закритих текстових одиниць, які можна класифікувати як «малу прозу», хоча формально вони не є однорідними. Вибір варіюється від анекдоту, історії, радіоп'єси, сатири, репортажу, щоденника, притчі, гротеску до зашифрованих та абсурдних історій. У рамках цього канону легші тексти через обмеження в часі можуть бути рекомендовані як додаткове домашнє читання. Однак іноді дуже простий твір пропонує найбільш можливі варіації в роботі над текстом, і тому варто використовувати його на практичних заняттях.

Таким прикладом простого тексту може служити оповідання Вольфганга Борхерта. „Das Brot", це історія часів другої світової війни, яка розповідає, як стара жінка застає свого чоловіка на кухні вночі, коли він бере частину пайки хліба, відкладеної на наступний день, краде цей хліб і намагається приховати це від неї. Після майже 40 років шлюбу вона сильно страждає від цієї зради та недовіри, а наступного дня дає йому свою власну пайку під приводом, що не може перетравлювати їжу ввечері.

Слід зауважити, що аудиторній роботі над текстом має передувати інтенсивне домашнє читання творів. Однією 3 форм роботи над текстом на занятті може стати читання вголос діалогічних частин тексту. Для цього студенти працюють в групах. Той, хто читає відповідну роль, повинен зуміти передати емоційний стан героя, наприклад те, що чоловік здивований, спійманий на гарячому і відчуває себе злодієм; відтворити його невпевненість, сором і каяття. Те саме стосується і ролі жінки. Це надає студентам усвідомлення функції невербальної комунікативної складової. Третій студент бере на себе роль коментатора, де він має виступати у стилі автора - короткими реченнями, що містять лише фактичну інформацію.

У наступному завданні можна вдатися до імпровізації даної сцени з тексту, яку слід мовно розширити, довільно продовживши розмову (чоловік, розгублений, завжди шукає нових виправдань, жінка заперечує сказане). Для цього студенти записують відповідні мовні засоби та ситуаційну аргументацію (як напр., ,, das ist mir verdächtig “, , $d u$ wolltest mich hintergehen/hinters Licht führen/ zum Narren halten “; ,, na, mein Alter "; ,, hör mal zu, Alte"). Усі ідеї мають бути виправлені і доповнені за допомогою викладача. Також потрібно звернути увагу на стилістичні відхилення деяких виразів від стандартної літературної мови.

Наступною можливістю роботи над мовою текста може стати детальний опис кухні, рухів жінки в темряві (sie tappte/befühlte die Wand/schleppte sich/war schlaftrunken/ gähnte) або ж опис того, як чоловік возиться з хлібом (Brotlaib, Brotkruste, Stulle, Krümmel, harte Brotkanten, stumpfes Messer )

Домашнім завданням може бути вільна фантазія щодо продовження/ фіналу історії. Емоційна реакція студентів на запропоновані іншими продовження/фінали історії як то здивування, неприйняття, ідентифікація тощо, може бути аргументом того факту, що не лише ліричні жанри здатні викликати емоційно забарвлену рефлексію і внутрішній досвід.

Фаза роботи над стилістичними засобами тексту має базуватися на тому, щоб студенти розвивали навички усвідомлення власного досвіду рефлексії. Слід виділити ключові слова в тексті (sagen-denken-antworten-essen-Brot-dunkelkalt) і визначити їх функцію в тексті і інтерпретувати символічне значення «хліба», що дав назву розповіді та інших символів (наприклад, «світла» як: надії, розуму, щирісті, миру, перемоги добра в людині тощо).

Останнім завданням може бути есе-роздум на тему: «Чому Вольфганг Борхерт обрав таку наподив безпристрасну, тверезу, лаконічну форму для своєї історії часів війни та 3 яким аспектом проблеми війни він намагався художньо впоратися?».

Для презентації чергового тексту Вольфганга Борхерта пропонується використати аудіозапис. Треба зазначити, що презентації у формі аудіозаписів відіграють важливу роль. Дуже часто у повсякденному навчальному процесі вони пропонують (майже) єдину можливість почути носіїв мови 3 усіма особливостями їхнього мовлення. Зазвичай студенти (учні) дуже швидко звикають до мови своїх викладачів (вчителів) і можуть зрозуміти іiі без особливих труднощів. Все змінюється, якщо йдеться про аудіозаписи, де швидкість мовлення, висота тону, модуляція голосу та інтонація різних ораторів незвичні і тому вимагають найвищого рівня концентрації, але в той же час наявна можливість усвідомлення зразкової валідності іншомовного висловлювання. Саме тому, що рівень складності в розумінні носіїв мови на слух вищий, часте використання аудіозаписів $€$ найбільш продуктивним (також, наприклад, у формі індивідуального або факультативного домашнього завдання), тому що готує студента (учня) до безпосереднього контакту з носіями мови.

За змістом другого оповідання Вольфганга Борхерта „Die drei dunklen Könige“ троє солдатів, фізично і психічно скалічених, повертаються 3 фронту на батьківщину. По дорозі вони залишаються в самотньому будинку, у вікні якого вони побачили світло. Це Святвечір. У будинку вони спіткають жінку з її новонародженою дитиною. Батько сім'ї повертається з відчайдушного і безнадійного полювання на хмиз та їжу. Він шукає 
когось, кому міг би «вдарити в лице» за свою долю. Але його ненависть не спрямована проти цих солдатів. Вони дарують дитині та жінці свої дуже бідні подарунки - найкраще, що у них було, i мовчки зникають у темряві. Чоловік вважає їх дивними святими.

Без попереднього ознайомлення студентів із друкованим текстом, їм пропонується спочатку прослухати аудіозапис цього оповідання. Після першого прослуховування студентам мають бути запропоновані вправи на нову лексику і глобальне розуміння прослуханого. Тоді студенти мають поміркувати, як би могла бути названа ця історія. Дуже по-різному сформульовані заголовки виявлять перші емоційні реакції на текст. Чергова вправа на розуміння змісту оповідання має бути спрямована на розуміння подробиць, а саме, студенти під час прослуховування роблять нотатки, відповідаючи на запитання щодо змісту оповідання. Потім студенти, працюючи в групах, порівнюють відповіді між собою. Наприкінці групової роботи, кожна група має записати свій варіант відповіді на диктофон. Презентація може відбуватися у змішаних групах, що дозволить студентам обговорити між собою деякі розбіжності в розумінні змісту і виправити власні помилки.

Наступне завдання може включати інше джерело. Студенти знайомляться з біблійною історією про трьох мудреців зі Сходу і мають пов'язати іiі 3 текстом Вольфганга Борхерта. Роблячи це, вони визнають для себе притчевий характер історії. Наступним завданням може бути визначити такі терміни, як запозичення, метафора, літературний паралелізм, притча, персонифікація та пояснити їх за допомогою тексту. Потім в групах студенти мали шукати інші приклади персонифікованих об'єктів, наприклад, das hohle Fenster gähnte «порожнє вікно позітхало», die dunkle Stadt zitterte vor Kältе «темне місто тремтіло від холоду», der Tisch wärmte sich am Ofen «стіл зігрівався біля neчi», kleine Feuerfunken schlugen Purzelbäume «маленькі іскри вогню робили сальта» тощо.

Мала проза Вольфганга Борхерта, на нашу думку, якнайкраще підходить для загострення відчуття читачем стилістичних характеристик художніх текстів. Саме виходячи 3 цих міркувань, студенти можуть працювати над наступним завданням в парах. Отримавши уривки 3 різних історій Вольфганга Борхерта, вони мають визначити і прокоментувати стилістичні особливості цих уривків тексту, які притаманні автору. Якщо студенти визначать їх як такі, що характерні для прози Вольфганга Борхерта, вони мають довести свою думку з урахуванням знань, які вони вже здобули про письменника та його стиль. Наприкінці варто провести коротку дискусію, яка має розкрити почуття, 3 якими молоді люди став- ляться до так званої повоєнної літератури. Що їх особисто приваблює найбільше: типові описи боїв чи психологічна перспектива оповідань? Визнання того, що і як ці, здавалося б, банальні, щоденні історії Вольфганга Борхерта «глибоко вразили», «потрясли», «зачарували», «закарбувалися у пам'яті», стали для студентів «цінним досвідом», $\epsilon$ найкращим підтвердженням того, що вибір текстів є правильним та оптимальним для досягнення освітніх і виховних цілей. Таким чином, працюючи 3 оригінальними німецькомовними художніми текстами, що належать до жанру малої прози, можна розвивати у студентів-філологів навички синтезу та міркування, а також привернути увагу до стильової специфіки творчості окремих письменників.

Іншим письменником, мала проза якого має надати репрезентативне розуміння особливостей усієї його творчості, є Генріх Бьолль. Спочатку варто проаналізували його відомі оповіді на воєнну тематику, такі як „,Wanderer, kommst du nach Spa... “ та/або „Lohengrins Tod“, аби порівняти їх 3 тематично спорідненими оповіданнями Вольфганга Борхерта. Щоб розширити спектр, а також представити Генріха Бьолля як іронічного мораліста і сатирика, можуть бути представлені ще два тексти: „Der Lacher“ та „Anekdote zur Senkung der Arbeitsmoral “.

В оповіданні „Der Lacher“ чоловік розповідає про свою дивну професію, в якій він досяг великих комерційних успіхів. Він є дуже затребуваним «митцем» 3 неабиякими здібностями: „Das Lachen Amerikas ruht in meiner Brust, das Lachen Afrikas, weißes, rotes, gelbes Lachen, und gegen ein entsprechendes Honorar lasse ich es er klingen, so wie die Regie es vorschreibt" ("CMix Америки - в моїх грудях, сміх Африки, білий, червоний, жовтий сміх - $i$ за відповідну плату я дозволяю йому звучати так, як забажає режисер»). Проте як приватна людина він поводить себе дуже серйозно і йому невідомо, як звучить його власний сміх. Ураховуючи дату написання, 1952 рік, очевидним стає сатиричний характер оповідання.

Спочатку роботи над текстом ми пропонуємо визначити сміх як фізіологічний, психологічно обумовлений процес і описати різні ситуації, на які люди можуть реагувати сміхом. Потім студенти мають ознайомитися зі сталими виразами, до складу яких входить дієслово lachen «cмiятися», як, наприклад, „Ich kann übers ganze Gesicht lachen!“ , „Ich muss mir vor Lachen die Seiten halten!", „,Wenn ich ein Gelächter anstimme, lachen bald die Leute Tränen!“, ,Wenn ich eine Lache anschlage, dann...", „Dass ich nicht lache!", „Mir ist aber gar nicht nach Lachen zumute", „Da lachen ja die Hühner! “. 
До ідіоматичних виразів варто дібрати відповідності у рідній мові, всі вони мають бути детально пояснені, щоб виключити можливі непорозуміння. Надалі студенти закріплюють ідіоматичні вирази з дієсловом lachen у формі рольової гри. У рольовій грі «професійні смішники» повинні хвалитися своїми вміннями, використовуючи нещодавно вивчені фрази. Інші учасники - «друзі дитинства» відомого смішника - мають заперечувати все, використовуючи інші вирази з дієсловом lachen. Рольову гру можна провести у різних формах, як то «Пінг-понг», «Акваріум» тощо.

Наступним завданням може бути реконструювати повсякденне життя «професійного смішника». Студенти мають розіграти типову ситуацію, запропоновану у тексті, і креативно розширити iii, як вважають за потрібне. Наступним завданням може бути прокоментувати незвичний спосіб життя свого чоловіка, який сміється у вигляді монологу жінки (фігура, яка не фігурує в сюжеті). Кожен коментар може бути зроблений з різною емоційною забарвленістю (жаль, злість, гордість, тощо). «Слухачі» мають вирішити, з якою з реакцій жінки вони, швидше за все, ототожнюватимуться, і коротко обгрунтувати це рішення.

У завершальній дискусії слід більш точно зосередились на деяких аспектах. Спочатку можна з'ясували різницю між професією та роботою, покликанням людей до роботи та суто комерційним ставленням до професії, яку вони виконують. Виходячи із власного досвіду, можемо зазначити, що студенти наводять дуже цікаві аргументи. Деякі стверджують, що таких професій не існує, і що історія, яку розповідає Генріх Бьолль, парадоксальна і смішна сама по собі, є чистою фантазією сатирика. Інші висловлюють думку, що автор виявив симпатію до зображеного ним «професійного смішника», висміюючи суспільство, яке змушує людей сліпо і некритично долучатись до кожного бізнесу з економічної необхідності. Висловлювання, що стосуються двозначності людської природи, внутрішнього конфлікту чутливої людини, яка скидає маску лише перед собою і яка, як приватна особа, бачить себе виставленою на милість убогості світу, який деградує і змушує людей вести абсурдне полювання на прибуток навіть проти їхньої волі, свідчать про глибокий вплив тексту на студентів. Багато студентів підтвердили доречність літературних текстів для розвитку здатності критичного розуміння причин людських вчинків.

Таким чином, інтерпретація оригінальних німецькомовних художніх текстів розвиває іншомовні комунікативні навички студентів, їхні критичні і творчі здібності, викликає не лише естетичні, а й етичні судження. Інтерпретація художгнього тексту забезпечує сприйняття і одно- часно контролює, чи справді це сприйняття відбулося. Саме тому, на наш погляд, вона $є$ незамінним елементом у роботі над будь-яким оригінальним літературним текстом.

Через інший твір Генріха Бьолля ,,Anekdote zur Senkung der Arbeitsmoral “, що також належить до жанру малої прози, можна також запропонувати студентам широкі можливості для індивідуального сприйняття та інтерпретації. Для того, щоб отримати відповідний настрій щодо сатиричної направленості тексту, можна запропонувати студентам вибрати «класичний» анекдот вдома для презентації групі. Потім студенти мають зібрати детальну інформацію про загальну характеристику анекдоту як літературної форми. Порівнявши окремі «класичні» анекдоти, студенти мають перетворити текст Генріха Бьолля на «класичний» анекдот. Однак попередньо потрібно знайти в тексті мораль. У цьому випадку дата написання тексту (1963р.) може бути також важливим посиланням на історичні витоки сатири у творі. За допомогою кількох додаткових запитань викладач має допомогти студентам правильно зрозуміти інтенцію тексту. 3 огляду на це важливо розглянути, чи не слід сприймати прийменник „zur“, який використовується в заголовку тексту, як особливо влучне втілення основної ідеї твору? Саме через нього назва звучить не так «нейтрально», як, наприклад, „Anekdote von der Senkung der Arbeitsmoral“. Сформульована таким чином, основна ідея безпосередньо стосується висвітленого в тексті явища, але саме зміна прийменника дозволила критично-сатиричній ідеї оповідача розкритися вже з першого речення.

Після цього припущення для всіх має стати зрозумілим, що застереження проти нелюдської «гонитви за грошима», звичайно, може стосуватися лише завзятого «мислителя прибутку» - туриста.

Тепер можна шукати в тексті докази ставлення оповідача до цього персонажа, характеризуючи його 3 точки зору ледачого, спокійного, самодостатнього рибалки. Так само можна вдатися до характеристики рибалки 3 точки зору амбіційного, ненажерливого туриста.

Сцена, описана в оповіданні, може бути розширена також у формі рольвої гри. Студенти працюють у групах та отримують диференційовані завдання, як-то зняти на відео діалог рибалки 3 туристом, монолог рибалки та монолог туриста за цим інцидентом. Відзняті відеороліки презентуються і обговорюються в загальній групі. Індивідуальним завданням наприкінці обговорення може бути написання есе або блогу, в якому б студенти роздумували про зустріч з рибалкою з точки зору а) спантеличеного, б) освіченого туриста.

Література відкриває окрему сферу, вона розкриває особливий внутрішній світ, що $є$ незамін- 
ним і неповторним. I найважливішим завданням викладача є допомогти молодим людям отримати доступ до цього світу. Лише літературний текст, оскільки він не $є$ виключно «деградованим» до граматичних та лексичних вправ, пропонує можливість не тільки розвивати чотири основні мовні компетенції, але й мати справу 3 художньо-естетичним. Як жоден інший тип тексту, він сприяє розвитку соціальних компетентностей, бажанню спілкуватися та готовності до розмови, розвиває вміння робити судження, вчить критичній оцінці, формує особистість, дає імпульс для роздумів та соціально орієнтованого спілкування.

На нашу думку, не існує єдиного абсолютно дієвого методу роботи над літературним текстом. Викладач має покладатися тут на власну інтуїцію.
Однак найкращим є той метод, який є поєднанням різних форм роботи, включаючи елементи гри, і дозволяє зрозуміти текст як глибоку структуру. Дуже важливо працювати над креативом та творчою уявою студентів та стимулювати вміння вільно виражати іноземною мовою логічні міркування, критично-оціночні судження та вести полемічні дискусії. Якщо ж студентові вдається висловлюватися в природньому темпі, з приблизно правильною інтонацією та активним використанням словникового запасу, можна говорити про успіх. Найкраща ж ціна за всі зусилля - справжнє бажання висловлюватись іноземною мовою, спонтанна емоційна реакція, нестримне красномовство, або власний вербалізований досвід - все, що може викликати лише художня література.

\section{ЛITEPATУРA}

1. Bekes P. „Extrakte des Lebens“ - Kurzprosa im Deutschunterricht. Deutschunterricht. Themenheft: Epische Kurzformen 63, Heft 2, 2010. S. 4-8.

2. Bellmann W. Klassische deutsche Kurzgeschichten. Stuttgart: Reclam, 2003. 363 S.

3. Frickel D. A. Gattungswissen und literarisches Verstehen am Beispiel Kleiner Prosa oder: Von „Beulen, die sich der Verstand beim Anrennen an die Grenze der Sprache geholt hat". Pieper I., Wieser D. Fachliches Wissen und literarisches Verstehen. Studien zu einer brisanten Relation. (Beiträge zur Literatur- und Mediendidaktik 22). Frankfurt am Main: Peter Lang, 2012. S. 71-90.

4. Frickel D. A. Was Gattungsadaptionen Kleiner Prosa erzählen - Gattungsmuster als Ausgangspunkt literarischen Verstehens oder Warum die Vermittlung von Gattungswissen Sinn macht. Dargestellt an einer exemplarischen Unterrichtssequenz. Frickel D. A., Kammler C., Rupp G. Literaturdidaktik im Zeichen von Kompetenzorientierung und Empirie. Kompetenzen und Probleme. Freiburg i. Br. : Fillibach, 2012. S. 41-66.

5. Göttsche D. Kleine Prosa in Moderne und Gegenwart. Münster: Aschendorff, 2006. 143 S.

6. Kniffka G., Siebert-Ott G. Deutsch als Zweitsprache. Lehren und lernen. 2.Auflage, Paderborn : Schöningh UTB, 2009. $244 \mathrm{~S}$.

7. Krechel R. Konkrete Poesie im Unterricht des Deutschen als Fremdsprache. Heidelberg : Julius Groos Verlag, 1991.277 S.

8. Krumm H.-J., Fandrych C., Hufeisen B., Riemer C. Deutsch als Fremd und Zweitsprache. Ein internationales Handbuch. 2 Bände. Berlin/New York : de Gruyter, 2010. 1894 S.

9. Löschmann M., Schröder G. Literarische Texte im Fremdsprachenunterricht. Leipzig: Enzyklopädie, 1988. $89 \mathrm{~S}$.

10. Marx L. Die deutsche Kurzgeschichte. Stuttgart : Metzler, 2005. 240 S.

11. Meyer A.-R. Die deutschsprachige Kurzgeschichte. Eine Einführung. Berlin : Erich Schmidt, 2014. 216 S.

12. Nickel-Bacon I. Positionen der Literaturdidaktik - Methoden des Literaturunterrichts. Groeben N., Hurrelmann B. Empirische Unterrichtsforschung: Literatur- und Lesedidaktik. Weinheim : Juventa, 2006. S. 95-114.

13. Riehme J. Zur Arbeit am literarischen Text im Fremdsprachenunterricht. Deutsch als Fremdsprache Heft 12/1. Leipzig : Herder-Institut, 1975. S. 3-15

14. Spinner K. H. Kurzgeschichten - Kurze Prosa. Grundlagen - Methoden - Anregungen für den Unterricht. Seelze : Klett-Kallmeyer, 2012. 176 S.

15. Zabka T. Didaktische Analyse literarischer Texte. Theoretische Überlegungen zu einer Lehrerkompetenz. Frickel D. A.. Kammler C., Rupp G. Literaturdidaktik im Zeichen von Kompetenzorientierung und Empirie. Kompetenzen und Probleme. Freiburg i.Br. : Fillibach, 2012. S. 139-162.

\section{REFERENCES}

1. Bekes P. (2010) „Extrakte des Lebens“ - Kurzprosa im Deutschunterricht [„Extracts of Life” - short prose in German lessons]. Deutschunterricht. Themenheft: Epische Kurzformen 63 [German lessons. Special issue: Epic Short Forms 63], Vol. 2. P. 4-8.

2. Bellmann W. (2003) Klassische deutsche Kurzgeschichten. [Classic German short stories]. Stuttgart : Reclam. 363 p. 
3. Frickel D. A. (2012) Gattungswissen und literarisches Verstehen am Beispiel Kleiner Prosa oder: Von „Beulen, die sich der Verstand beim Anrennen an die Grenze der Sprache geholt hat" [Genre knowledge and literary understanding using the example of small prose or: From „bumps that the mind has got when running to the limit of language"]. Pieper I., Wieser D. Fachliches Wissen und literarisches Verstehen. Studien zu einer brisanten Relation. (Beiträge zur Literatur- und Mediendidaktik 22) Professional knowledge and literary understanding. Studies on an explosive relationship. (Contributions to literature and media didactics 22). Frankfurt am Main : Peter Lang. P. 71-90.

4. Frickel D. A. (2012) Was Gattungsadaptionen Kleiner Prosa erzählen - Gattungsmuster als Ausgangspunkt literarischen Verstehens oder Warum die Vermittlung von Gattungswissen Sinn macht. Dargestellt an einer exemplarischen Unterrichtssequenz [What genre adaptations of small prose tell - genre patterns as a starting point for literary understanding or why it makes sense to impart genre knowledge. Shown in an exemplary lesson sequence]. Frickel D. A., Kammler C., Rupp G. Literaturdidaktik im Zeichen von Kompetenzorientierung und Empirie. Kompetenzen und Probleme [Literature didactics based on competence orientation and empiricism. Skills and problems]. Freiburg i. Br. : Fillibach. P. 41-66.

5. Göttsche D. (2006) Kleine Prosa in Moderne und Gegenwart [Small prose in modern and present]. Münster : Aschendorff. 143 p.

6. Kniffka G., Siebert-Ott G. (2009) Deutsch als Zweitsprache. Lehren und lernen [German as second language. Teach and learn]. 2nd Edition, Paderborn: Schöningh UTB. 244 p.

7. Krechel R. (1991) Konkrete Poesie im Unterricht des Deutschen als Fremdsprache [Concrete poetry in lessons of German as a foreign language]. Heidelberg : Julius Groos Verlag. 277 p.

8. Krumm H.-J., Fandrych C., Hufeisen B., Riemer C. (2010) Deutsch als Fremd- und Zweitsprache. Ein internationales Handbuch [German as a foreign and second language. An international manual]. 2 volumes. Berlin/New York : de Gruyter, 1894 p.

9. Löschmann M., Schröder G. (1988) Literarische Texte im Fremdsprachenunterricht [Literary texts in foreign language lessons]. Leipzig: Enzyklopädie. 89 p.

10. Marx L. (2005) Die deutsche Kurzgeschichte [The German short story]. Stuttgart: Metzler. 240 p.

11. Meyer A.-R. (2014) Die deutschsprachige Kurzgeschichte. Eine Einführung [The German-language short story. An introduction]. Berlin : Erich Schmidt. 216 p.

12. Nickel-Bacon I. (2006) Positionen der Literaturdidaktik - Methoden des Literaturunterrichts [Positions in literature didactics - methods of teaching literature]. Groeben N., Hurrelmann B. Empirische Unterrichtsforschung: Literatur- und Lesedidaktik [Empirical teaching research: literature and reading didactics]. Weinheim : Juventa. P. 95-114.

13. Riehme J. (1975) Zur Arbeit am literarischen Text im Fremdsprachenunterricht [To work on the literary text in foreign language lessons]. Deutsch als Fremdsprache [German as a foreign language] Vol. 12/1. Leipzig : Herder-Institut. P. 3-15.

14. Spinner K. H. (2012) Kurzgeschichten - Kurze Prosa. Grundlagen- Methoden - Anregungen für den Unterricht [Short stories - short prose. Basics - methods - suggestions for teaching]. Seelze : KlettKallmeyer. $176 \mathrm{p}$.

15. Zabka T. (2012) Didaktische Analyse literarischer Texte. Theoretische Überlegungen zu einer Lehrerkompetenz [Didactic analysis of literary texts. Theoretical considerations on a teacher competence]. Frickel D. A., Kammler C., Rupp G. Literaturdidaktik im Zeichen von Kompetenzorientierung und Empirie. Kompetenzen und Probleme [Literature didactics based on competence orientation and empiricism. Skills and problems]. Freiburg i.Br. : Fillibach. P. 139-162. 